\title{
Agro-Morphological and Genetic Parameters of some Cowpea Genotypes
}

\author{
Shereen M. El-Nahrawy 1
}

\begin{abstract}
Success of most crop improvement programs depends mainly upon the existence of the genetic variability and the heritability of desirable traits in the material under selection. Magnitude and type of genetic variability are important for determining the selection criteria and breeding schemes to be used for improvement purposes. Three related experiments were conducted at Sakha Agricultural Research Station, Agricultural Research Center during three successive summer seasons; 2013-2015 to evaluate 24 cowpea genotypes including the check variety (Balady) and to select the best ones considering the yield and yield components under the study. Data revealed that highly significant differences exist among the genotypes for most the studied traits The result, however, revealed The genotype (G12) had the highest values for total fresh $(25.8 \mathrm{~kg} / \mathrm{plot})$ and dry yield $(2.639 \mathrm{~kg} / \mathrm{plot})$. On the other hand, G5 showed the lowest value $(10.6 \mathrm{k} / \mathrm{plot})$ for total fresh yield. The genotype (G4) surpassed the other genotypes in both evaluated seasons; 2014 and 2015 for all the studied traits. This may indicate the possibility to carry out a selection program to improve and develop new cultivar. In addition, results showed considerable variation among the genotypes in broad sense heritability estimate (h2) in 2013 and was $60.9 \%$ and $99 \%$ for the stem diameter and fresh yield for second cut, respectively. On the other hand, the heritability estimates were $82.7 \%$ and 98.9\% for number of branches and dry yield for the first cut; respectively, in 2014 and $83.1 \%$ and $99.3 \%$ for number of branches for first cut, and fresh yield for second cut; respectively, in 2015.

The genetic relationship among genotypes based on agro-morphological analysis showed significant variation among the genotypes over all the traits under the study. High similarity between (G20) and (G21) in 2013 and a close relation between (G3) and (G4) in 2014 and 2015 had achieved. Similarity level ranged from $43.98 \%$ to $96.02 \%$ in the first season (2013) and from $19.55 \%$ to $83.39 \%$ in the second season (2014) and from $21.91 \%$ to $84.17 \%$ in the third season (2015).
\end{abstract}

Keywords: Forage cowpea, Cluster analysis, Heritability in broad sense, Phenotypic and Genotypic coefficients of variation Genetic advance as a percent of mean.

\section{INTRODUCTION}

There is a very wide gap between the productions of green forage and the demanded which affect meat or milk production in Egypt. Moreover, the acute shortage of feed is during summer season (Hathout, 1987).
Cowpea (Vigna unguiculata sp. L. Walp) forms an integral part of a sustainable agriculture and land use system (Ogbonnaya et al., 2003). Cowpea plays considerable role in the nutritional balance and economy of the rural population in West Africa subregion (Krasova-Wade et al., 2006). It is a food legume crop that plays an important role in the lives of millions of people in Africa, which serves to improve the nutrient level. Cowpea is grown for both grain and fodder exhibiting wide scale of variability. The crude protein content is $5 \%$ and $23 \%$ on fresh and dry leaves; respectively, (Aravindham et al., 1995). Cowpea forms excellent forage and gives heavy vegetative growth which covers the ground well and helps tolerate the soil erosion. As a leguminous crop, it fixes about $240 \mathrm{Kg} / \mathrm{ha}$ of atmospheric nitrogen and make available $60-70 \mathrm{~kg} / \mathrm{ha}$ nitrogen for succeeding crop grown in rotation with it (Dumet et al., 2008, Musvosci, 2009). Moreover, it is a very good crop to be used in feeding animal during summer for its high quality and quantity and nutritive value.

The success of good breeding and selection program usually depends on the genetic variability present in the breeding materials and the variation in the population. Heritability and genetic advance are importants selection parameters of different traits in the genetic stock, which facilitate evaluation and identification of suitable genotypes. It helps to select genotypes from different genetic population by choosing good genotypes for its improvement.

Phenotypic and genotypic coefficients of variation and heritability are very important indicators in improving traits (Denton \& Nwangburuk, 2011). Johanson et al., (1995) illustrated the importance of selection and evaluating varieties for quantitative and yield ability in any breeding program, therefore the varieties can be introduced to a given local environment.

The genetic diversity in cowpea genotypes would facilitate development of cultivars for adaptation to specific production constraints. The genetic similarities and differences of breeding materials could help sustain long term selection. Many workers (Damarany, 1994; Uguru, 1995; Pathmanathan et al., 1997; Ubi et al., 2001; Omoigui et al.; 2006) have calculated different components of variance, heritability and genetic advance

\footnotetext{
${ }^{1}$ Forage Crops Research Dept., Field Crops Res. Inst., ARC, Egypt

Received February 08, 2018, Accepted March 04, 2018
} 
for different characteristics in cowpea and have mentioned that selection was effective.

The objectives of the present study are evaluating 24 cowpea genotypes and selecting the best genotypes by focusing on genetic variability, heritability and genetic advance for yield and related traits. In addition, determine genetic relationships among evaluated and selected genotypes using similarity through number of quantitative traits which, mean that the differences between traits of tested genotypes attributed to the genetic divergence of it (Iqbal et al., 2008).

\section{MATERIALS AND METHODS}

The present study was carried out at Sakha Agricultural Research Station Farm during three successive summer seasons; 2013- 2015. Twenty-four cowpea genotypes were evaluated in a Randomized Complete Block Design with three replicates. Each replicate consisted of one row with $4 \mathrm{~m}$ long and $0.6 \mathrm{~m}$ wide with hills spaced at $30 \mathrm{~cm}$ between plants. After two weeks of sowing on $17^{\text {th }}$ of May 2013, stand was thinned to one plant per hill. Recommended agricultural practices were applied. Two cuts were taken during the growing season. The first and second cuts were taken on $17^{\text {th }}$ of July and $8^{\text {th }}$ of Sept. 2013, respectively. Data were recorded on fresh and dry forage yield $(\mathrm{kg} / \mathrm{plot})$, plant height $(\mathrm{cm})$ and stem diameter $(\mathrm{cm})$. Analyses of variance (ANOVA) using Discovery Statistic Soft Ware were issued. Estimation of genetic parameters according to the formula given by Robinson and Comstock (1955) was carried out.

Heritability $\left(\mathrm{h}^{2}\right)$ in broad sense was computed as a ratio of genetic variance to the total phenotypic variance as suggested by Hanson et al. (1956).

Genetic advance calculated according to the formula given by Johnson (1955). Selection at $20 \%$ intensity using yield and yield components was performed selected the best five genotypes in addition to the local variety as a check, and evaluated in two seasons; 2014 and 2015. The materials were sown in a randomized complete block design with four replicates. Plot size was $12 \mathrm{~m}^{2}(3 \times 4 \mathrm{~m})$ which consists of five rows, $1.8 \mathrm{~m}$ wide and $3 \mathrm{~m}$ long and $30 \mathrm{~cm}$ between hills. After two weeks, hills were thinned to one plant per hill. Recommended agricultural practices were applied. The

Table 1. Analysis of variance for traits under study of 24 cowpea genotypes at two cuts and total yield in 2013 season

\begin{tabular}{|c|c|c|c|c|c|c|c|c|c|c|c|}
\hline \multirow{2}{*}{ S.O.V. } & \multirow{2}{*}{ d.f } & \multicolumn{3}{|c|}{ Fresh yield (kg/plot) } & \multicolumn{3}{|c|}{ Dry yield (kg/plot) } & \multicolumn{2}{|c|}{ Plant height $(\mathrm{cm})$} & \multicolumn{2}{|c|}{ Stem diameter } \\
\hline & & Cut1 & Cut2 & Total & Cut1 & Cut2 & Total & Cut1 & Cut2 & Cut1 & Cut2 \\
\hline Rep. & 2 & 2.592 & 1.246 & 2.441 & 0.027 & 0.018 & 0.025 & 8.181 & 73.745 & 0.054 & 0.028 \\
\hline Geno & 23 & $* *$ & $* *$ & $* *$ & $* *$ & $* *$ & $* *$ & $* *$ & $* *$ & $* *$ & \\
\hline Geno. & 23 & 2.828 & 37.759 & 44.747 & 0.047 & 0.484 & 0.495 & 90.454 & 223.643 & 0.031 & 0.044 \\
\hline error & 46 & 0.826 & 0.376 & 1.122 & 0.008 & 0.005 & 0.013 & 7.978 & 7.707 & 0.012 & 0.017 \\
\hline
\end{tabular}

trials were fertilized with $30 \mathrm{~kg} \mathrm{P}_{2} \mathrm{O}_{5} /$ fad which were added during land preparation and $33 \mathrm{~kg}$ N/fad which were divided into two equal parts, part added before the first irrigation and the other after the first cut. Two cuts were taken in each season. The sowing dates were done on $10^{\text {th }}$ and $6^{\text {th }}$ of May in the two seasons, respectively. The $1^{\text {st }}$ and $2^{\text {nd }}$ cuts were taken on $10^{\text {th }}$ of July and $13^{\text {th }}$ of August in 2014, respectively. While, in 2015 the $1^{\text {st }}$ and $2^{\text {nd }}$ cuts were taken on $7^{\text {th }}$ of July and $11^{\text {th }}$ August, respectively. Data under study were recorded for the following traits; fresh and dry forage yield ( $\mathrm{kg} / \mathrm{plot})$, plant height $(\mathrm{cm})$, stem diameter $(\mathrm{cm})$ and number of branches/plant. The statistical analyses mentioned for the $1^{\text {st }}$ season earlier were carried out for the data of both the $2^{\text {nd }}$ and the $3^{\text {rd }}$ seasons.

\section{Cluster analysis:}

Genotypes were clustered using un-weighted pair group method using arithmetic average as outlined by Korach (1995). It was based on similarity matrix obtained with un-weighted pair group method using arithmetic average (UPGMA), and the relationships among genotypes were displayed as dendrogram calculated based on Jukes-Cantor Coefficient using PAST program.

\section{1-Genetic Variability:}

Analysis of variance showed that the mean squares for all studied traits; fresh and dry yield in the two cuts and total yield, plant height and stem diameter were highly significant among the genotypes at the first season 2013 (Table 1).

Table (2) shows means of four morphological traits under the study. Wide range of variations was observed among the 24-cowpea genotypes under comparison. The maximum value for the total fresh yield $(25.8 \mathrm{~kg} / \mathrm{plot})$ was detected for (G12), while the lowest value (10.6 $\mathrm{kg} / \mathrm{plot}$ ) was recorded for (G5). The results are in agreement with those reported by Davis et al. (1986).

It is worth mentioning that the (G.12) and (G.22) had the highest values for the total dry yield (2.639 and $2.676 \mathrm{Kg} / \mathrm{plot}$ ), respectively. On the other hand, (G5) had the lowest value $(1.218 \mathrm{Kg} / \mathrm{plot})$ for total dry yield. entor 
Table 2. Mean performance of the 24-cowpea genotypes for the four traits under study in 2013 season

\begin{tabular}{|c|c|c|c|c|c|c|c|c|c|c|}
\hline \multirow{2}{*}{ No } & \multicolumn{3}{|c|}{ Fresh yield (kg/plot) } & \multicolumn{3}{|c|}{ Dry yield (kg/plot ) } & \multicolumn{2}{|c|}{ Plant height (cm) } & \multicolumn{2}{|c|}{ Stem diameter(cm) } \\
\hline & Cut1 & Cut2 & Total & Cut1 & Cut2 & Total & Cut1 & Cut2 & Cut1 & Cut2 \\
\hline 1 & 7.3 & 13.3 & 20.7 & 0.741 & 1.467 & 2.207 & 53.3 & 70.6 & 0.567 & 1.1 \\
\hline 2 & 8.0 & 8.9 & 16.9 & 0.904 & 1.068 & 1.972 & 49.0 & 71.0 & 0.500 & 1.2 \\
\hline 3 & 6.3 & 6.5 & 12.8 & 0.741 & 0.780 & 1.521 & 51.7 & 46.1 & 0.667 & 1.1 \\
\hline 4 & 8.0 & 14.0 & 21.9 & 0.874 & 1.694 & 2.599 & 60.3 & 67.7 & 0.833 & 1.2 \\
\hline 5 & 6.5 & 4.1 & 10.6 & 0.735 & 0.484 & 1.218 & 48.3 & 53.3 & 0.533 & 1.2 \\
\hline 6 & 9.6 & 12.0 & 21.6 & 0.915 & 1.500 & 2.415 & 57.3 & 68.0 & 0.567 & 0.9 \\
\hline 7 & 7.9 & 11.0 & 18.9 & 0.739 & 1.210 & 1.949 & 52.3 & 68.3 & 0.633 & 1.1 \\
\hline 8 & 8.8 & 10.1 & 19.0 & 0.880 & 1.230 & 2.110 & 67.3 & 77.0 & 0.433 & 1.1 \\
\hline 9 & 6.5 & 15.3 & 21.8 & 0.764 & 1.763 & 2.528 & 61.0 & 55.6 & 0.767 & 1.3 \\
\hline 10 & 9.5 & 3.0 & 12.5 & 1.026 & 0.300 & 1.326 & 48.0 & 56.0 & 0.400 & 0.9 \\
\hline 11 & 9.2 & 12.3 & 21.5 & 0.963 & 1.233 & 2.196 & 55.3 & 67.3 & 0.533 & 1.2 \\
\hline 12 & 9.8 & 16.0 & 25.8 & 1.039 & 1.600 & 2.639 & 49.0 & 84.0 & 0.600 & 1.3 \\
\hline 13 & 9.2 & 11.3 & 20.5 & 0.868 & 1.232 & 2.100 & 57.0 & 68.3 & 0.600 & 1.1 \\
\hline 14 & 8.4 & 17.0 & 25.4 & 0.759 & 1.819 & 2.578 & 48.7 & 70.3 & 0.600 & 1.2 \\
\hline 15 & 8.6 & 11.7 & 20.3 & 0.777 & 1.283 & 2.060 & 61.7 & 72.3 & 0.733 & 1.3 \\
\hline 16 & 8.1 & 8.6 & 16.7 & 0.807 & 0.929 & 1.735 & 54.7 & 54.3 & 0.667 & 0.8 \\
\hline 17 & 8.4 & 11.7 & 20.1 & 0.907 & 1.248 & 2.156 & 55.0 & 68.3 & 0.533 & 1.2 \\
\hline 18 & 8.0 & 16.0 & 24.0 & 0.728 & 1.840 & 2.568 & 50.3 & 68.3 & 0.600 & 1.2 \\
\hline 19 & 8.4 & 13.3 & 21.7 & 0.672 & 1.613 & 2.285 & 47.3 & 62.3 & 0.500 & 1.0 \\
\hline 20 & 7.4 & 11.8 & 19.2 & 0.656 & 1.396 & 2.052 & 55.0 & 58.3 & 0.700 & 1.2 \\
\hline 21 & 8.0 & 10.8 & 18.8 & 0.560 & 1.127 & 1.687 & 55.3 & 58.3 & 0.567 & 1.2 \\
\hline 22 & 9.5 & 15.2 & 24.6 & 0.871 & 1.805 & 2.676 & 55.6 & 71.6 & 0.600 & 1.2 \\
\hline 23 & 8.0 & 10.2 & 18.1 & 0.653 & 1.118 & 1.772 & 61.3 & 64.3 & 0.700 & 1.1 \\
\hline 24 & 7.8 & 13.7 & 21.5 & 0.642 & 1.503 & 2.146 & 63.7 & 74.3 & 0.633 & 1.1 \\
\hline F.test & $* *$ & $* *$ & $* *$ & $* *$ & $* *$ & $* *$ & $* *$ & $* *$ & $* *$ & $* *$ \\
\hline L.S.D 0.01 & 1.994 & 1.345 & 2.324 & 0.196 & 0.155 & 0.250 & 6.197 & 6.091 & 0.240 & 0.286 \\
\hline L.S.D 0.05 & 1.494 & 1.008 & 1.741 & 0.147 & 0.116 & 0.187 & 4.642 & 4.642 & 0.180 & 0.214 \\
\hline
\end{tabular}

The genotype ( $\left.\begin{array}{l}\mathrm{G} 8 \\ 8\end{array}\right)$ surpassed the rest of the genotypes for plant height trait at the first cut with value of $67.3 \mathrm{~cm}$, but at the second cut $(\mathrm{G} 12)$ had the highest value of $84 \mathrm{~cm}$. Moreover, (G4) was the best genotype regarding the stem diameter in the first cut. Genotype (G12) had values of $0.833 \mathrm{~cm}$ and $1.3 \mathrm{~cm}$ for the first and second cuts, respectively. These data might indicate a very wide variation among genotypes under study for considered traits. Therefore, it might be used to identify different cowpea genotypes (Sharawy and El-Fiky, 2003).

The analysis of variance of the selected five cowpea genotypes and local variety (Balady) as a check variety is shown in Table 3. Data revealed that the existence of highly significant differences among the genotypes for all the studied traits in the two seasons; (2014 and 2015).

\section{2-Response to Selections:}

Table (5) shows means of traits under study at the second season (2014). The results show that, G4 surpassed the rest of the genotypes for all the studied traits with value of 64.7 and $8.06 \mathrm{Kg} /$ plot for the total fresh and dry forage yield, 77 and $83 \mathrm{~cm}$ for plant height, 0.88 and 0.80 for stem diameter, and 8 and 10 for the number of branches per plant for the first and second cuts, respectively. On the other hand, the lowest value was detected for (G6) for all traits in all cuts. In addition, G4 and G6 behaved the same in $3^{\text {rd }}$ season.

Table (5) shows means of the five studied traits where $(\mathrm{G} 4)$ had value of $65.3 \mathrm{Kg} /$ plot for the total fresh forage yield while (G6) had $48.5 \mathrm{Kg} /$ plot. Regarding the total dry yield (G4) had the highest value of 7.768 and (G5) had the lowest value of 5.309 (Kg/plot). Concerning plant height trait (G4) had 76 and $85 \mathrm{~cm}$ for the first and second cut and (G4) had the lowest values; 69 and $71 \mathrm{~cm}$ for (G6). Regarding the stem diameter (G4) had 0.90 and 0.84 and (G6) had the lowest values of 0.80 and 0.70 for first and second cuts, respectively.

The numbers of branches were 8 and 10 for $(\mathrm{G} 4)$ while (G6) had the lowest values of 7 and 8 branches/plant found to be for first and second cuts, respectively.

The numbers of branches were 8 and 10 for (G4) while (G6) had the lowest values of 7 and 8 branches/plant found to be for first and second cuts, respectively. 
Table (6) shows the genotypic $\left(\square^{2} \mathrm{~g}\right)$, phenotypic variation $\left(\square^{2} \mathrm{p}\right)$, genotypic coefficient of variation (GCV), phenotypic coefficient of variance (PCV), broad sense heritability $\left(\mathrm{h}^{2}\right)$ and genetic advance as percent of mean, (GAM).

Estimates in 2013 season generally had higher PCV values than that of GCV which indicate of some environmental implication alongside genotypic reasons of variation observed between varieties used in this study. Phenotypic variance was higher than the genetic variance of all morphological traits. This observed variation may due to environmental factor rather than genetic. Similar results have been reported by Nwosu et al. (2013). The heritability in broad sense was significantly high for all the traits under investigation.

It ranged from $60 \%$ to $99.2 \%$ and considered important in selection of different cowpea genotypes from a population (Manggoel et al., 2012 \& Rashwan, 2010). The high heritability values indicate that the predominance of additive gene action in the expression of the traits which can be improved through single cycle of selection.

Table 3. Genetic parameters of some morphological traits for cowpea genotypes during 2013 season

\begin{tabular}{rlcccccccc}
\hline \multicolumn{1}{c}{ Traits } & \multicolumn{1}{c}{$\mathbf{X}$} & $\mathbf{}^{\mathbf{2}} \mathbf{\delta g}$ & $\mathbf{}^{\mathbf{\delta}} \mathbf{p}$ & $\mathbf{G . C . V}$ & $\mathbf{P . C . V}$ & $\left.\boldsymbol{( H}^{\mathbf{2}}\right) \boldsymbol{\%}$ & $\Delta \mathbf{g}$ & $\mathbf{G \%}$ \\
\hline 1 & Fresh yield cut1 & 8.22 & 1.001 & 1.414 & 12.18 & 14.47 & 70.8 & 117.8 & 14.3 \\
2 & Fresh yieldcut2 & 11.57 & 18.69 & 18.89 & 37.3 & 37.5 & 99.0 & 595.98 & 51.5 \\
3 & Total Fresh yield & 19.80 & 21.81 & 22.37 & 23.6 & 23.9 & 97.4 & 643.6 & 32.51 \\
4 & Dry yield cut1 & 0.801 & 0.020 & 0.024 & 17.4 & 19.1 & 82.9 & 17.8 & 22.2 \\
5 & Dry yield cut2 & 1.302 & 0.239 & 0.241 & 37.5 & 37.7 & 99.2 & 68.2 & 52.38 \\
6 & Total Dry yield & 2.103 & 0.241 & 0.248 & 23.7 & 23.3 & 97.2 & 67.6 & 32.14 \\
7 & Plant height cut1 & 54.9 & 275 & 31.5 & 9.5 & 10.2 & 87.3 & 685.9 & 12.49 \\
8 & Plant height cut2 & 65.68 & 108.3 & 112.2 & 15.8 & 16.1 & 96.5 & 1431.0 & 21.39 \\
9 & Stem diameter cut1 & 0.603 & 0.027 & 0.033 & 27.2 & 30.1 & 81.8 & 20.8 & 34.49 \\
10 & Stem diameter cut2 & 1.129 & 0.014 & 0.023 & 10.5 & 13.4 & 60.9 & 12.9 & 11.42 \\
\hline
\end{tabular}

Table4.Genetic parameters of some morphological traits for cowpea genotypes during 2014 and 2015 season

\begin{tabular}{|c|c|c|c|c|c|c|c|c|c|}
\hline No. & Traits 2014 & $' \mathbf{X}$ & ${ }^{2} \delta g$ & ${ }^{2} \delta p$ & G.C.V\% & P.C.V\% & $\left(\boldsymbol{H}^{2}\right) \%$ & $\Delta \mathbf{g}$ & G\% \\
\hline 1 & Fresh yield cut1 & 32.3 & 8.6 & 9.0 & 9.1 & 9.3 & 95.3 & 400.3 & 12.39 \\
\hline 2 & Fresh yield cut 2 & 27.6 & 15.1 & 15.6 & 14.1 & 14.3 & 96.8 & 535.3 & 19.39 \\
\hline 3 & Total Fresh yield & 56 & 44.8 & 45.7 & 12.0 & 12.1 & 98.0 & 927.5 & 16.56 \\
\hline 4 & Dry yield cut 1 & 3.750 & 0.761 & 0.769 & 23.3 & 23.4 & 98.9 & 121.4 & 32.37 \\
\hline 5 & Dry yield cut 2 & 3.250 & 0.157 & 0.324 & 12.2 & 17.5 & 48.5 & 38.6 & 11.87 \\
\hline 6 & Total Dry yield & 7.0 & 1.08 & 1.1 & 14.84 & 14.98 & 98.2 & 144.2 & 20.6 \\
\hline 7 & Plant height cut 1 & 72.5 & 15.2 & 15.9 & 5.5 & 5.3 & 95.5 & 533.1 & 7.35 \\
\hline 8 & Plant height cut 2 & 79 & 16.3 & 17.1 & 5.11 & 5.2 & 95.3 & 551.7 & 6.98 \\
\hline 9 & Stem diameter cut 1 & 0.798 & 0.013 & 0.014 & 14.3 & 14.8 & 92.8 & 15.4 & 19.29 \\
\hline 10 & Stem diameter cut 2 & 0.697 & 0.015 & 0.016 & 17.6 & 18.14 & 93.8 & 16.6 & 23.8 \\
\hline 11 & No.of branches cut 1 & 7.1 & 0.211 & 0.225 & 6.5 & 7.1 & 82.7 & 58.5 & 8.2 \\
\hline 12 & No.of branches cut 2 & 8.5 & 0.384 & 0.421 & 7.2 & 7.6 & 91.2 & 82.8 & 9.74 \\
\hline No. & Traits2015 & $' \mathbf{X}$ & ${ }^{2} \delta g$ & ${ }^{2} \delta p$ & G.C.V\% & P.C.V\% & $\left(H^{2}\right) \%$ & $\Delta \mathbf{g}$ & G\% \\
\hline 1 & Fresh yield cut 1 & 30.7 & 9.6 & 9.8 & 10.1 & 10.2 & 97.9 & 429.3 & 13.98 \\
\hline 2 & Fresh yield cut 2 & 29.1 & 13.3 & 13.4 & 12.5 & 12.6 & 99.3 & 508.8 & 17.48 \\
\hline 3 & Total Fresh yield & 59.8 & 45.8 & 46.2 & 11.3 & 11.4 & 99.1 & 943.3 & 15.77 \\
\hline 4 & Dry yield cut1 & 3.608 & 0.274 & 0.279 & 14.5 & 14.6 & 98.2 & 72.6 & 20.12 \\
\hline 5 & Dry yield cut 2 & 3.295 & 0.196 & 0.201 & 13.4 & 13.6 & 97.5 & 61.2 & 18.57 \\
\hline 6 & Total Dry yield & 6.903 & 0.940 & 0.950 & 14.04 & 14.12 & 98.9 & 134.9 & 19.54 \\
\hline 7 & Plant height cut 1 & 72.5 & 15.2 & 15.9 & 5.4 & 5.5 & 95.5 & 533.6 & 7.36 \\
\hline 8 & Plant height cut 2 & 79 & 16.3 & 17.1 & 5.1 & 5.2 & 95.3 & 551.8 & 6.98 \\
\hline 9 & Stem diameter cut 1 & 0.798 & 0.013 & 0.014 & 14.3 & 14.8 & 92.9 & 15.4 & 19.29 \\
\hline 10 & Stem diameter cut 2 & 0.697 & 0.015 & 0.016 & 17.6 & 18.1 & 93.7 & 16.6 & 23.8 \\
\hline 11 & No.of branches cut 1 & 7.0 & 0.211 & 0.254 & 6.5 & 7.1 & 83.1 & 58.6 & 8.37 \\
\hline 12 & No.of branches cut 2 & 9.0 & 0.384 & 0.421 & 7.3 & 7.6 & 91.2 & 82.8 & 9.2 \\
\hline
\end{tabular}


Table 5. Analysis of variance of six selected cowpea genotypes for the two cuts and the total yield in 2014 and 2015 seasons

\begin{tabular}{|c|c|c|c|c|c|c|c|c|c|c|c|c|c|}
\hline \multirow[t]{2}{*}{ S.O.V } & \multirow[t]{2}{*}{ d.f } & \multicolumn{3}{|c|}{$\begin{array}{c}\text { Fresh yield } \\
\text { (kg/plot) 2014 }\end{array}$} & \multicolumn{3}{|c|}{$\begin{array}{c}\text { Dry yield } \\
\text { (kg/plot ) } 2014\end{array}$} & \multicolumn{2}{|c|}{$\begin{array}{l}\text { Plant height } \\
\text { (cm) } 2014\end{array}$} & \multicolumn{2}{|c|}{$\begin{array}{c}\text { Stem diameter } \\
2014\end{array}$} & \multicolumn{2}{|c|}{$\begin{array}{c}\text { No. of } \\
\text { branches2014 }\end{array}$} \\
\hline & & Cut1 & Cut2 & Total & Cut1 & Cut1 & Total & $\begin{array}{c}\text { Cut1 } \\
\end{array}$ & Cut2 & Cut1 & Cut2 & Cut 1 & Cut2 \\
\hline Rep. & 3 & 0.778 & 2.523 & 4.334 & 027 & 0.100 & 0.153 & 3.444 & 1.444 & & & 0.050 & 0.116 \\
\hline \multirow{2}{*}{ Geno. } & \multirow{2}{*}{5} & $* *$ & $* *$ & $* *$ & $* *$ & & & & & & & & \\
\hline & & 26.867 & 47.022 & 137.355 & .770 & 0.971 & 3.240 & 47.600 & 51.200 & 0.014 & 016 & 0.764 & 1.262 \\
\hline & 15 & 1.111 & 1.649 & 2.861 & 0.026 & 0.033 & 0.060 & 2.111 & 2.378 & 0.002 & 0.001 & 0.130 & 0.109 \\
\hline \multirow[t]{2}{*}{ S.O.V } & \multirow[t]{2}{*}{ d.f } & \multicolumn{3}{|c|}{$\begin{array}{c}\text { Fresh yield (kg/plot) } \\
2015\end{array}$} & \multicolumn{3}{|c|}{ Dry yield (kg/plot ) } & \multicolumn{2}{|c|}{$\begin{array}{c}\text { Plant height }(\mathrm{cm}) \\
2015\end{array}$} & \multicolumn{2}{|c|}{$\begin{array}{l}\text { Stem diameter } \\
2015\end{array}$} & \multicolumn{2}{|c|}{$\begin{array}{c}\text { No. of } \\
\text { branches } 2015\end{array}$} \\
\hline & & Cut1 & Cut2 & Total & Cut1 & Cut1 & Total & Cut1 & Cut2 & Cut1 & Cut2 & Cut 1 & Cut2 \\
\hline Rep. & 3 & 1.403 & 0.419 & 2.449 & 0.020 & 0.013 & 0.041 & 1.042 & 1.667 & 0.001 & 0.000 & 0.034 & 0.023 \\
\hline \multirow{2}{*}{ Geno. } & \multirow{2}{*}{5} & ** & ** & $* *$ & ** & $* *$ & & ** & $* *$ & ** & & & \\
\hline & & 29.642 & 40.167 & 138.662 & 0.839 & 0.602 & 2.899 & 24.842 & 47.600 & 0.007 & & 1.296 & 1.787 \\
\hline error & 15 & 0.889 & 0.372 & 1.343 & 0.016 & 0.012 & 0.028 & 2.242 & 5.400 & 0.001 & 0.001 & 0.068 & 0.135 \\
\hline
\end{tabular}

Table 6. Mean performance of the six cowpea genotypes for the four traits in 2014 season

\begin{tabular}{|c|c|c|c|c|c|c|c|c|c|c|c|c|}
\hline \multirow[t]{2}{*}{ Genotypes } & \multicolumn{3}{|c|}{ Fresh yield(kg/plot) } & \multicolumn{3}{|c|}{ Dry yield (kg/plot ) } & \multicolumn{2}{|c|}{$\begin{array}{c}\text { Plant height } \\
(\mathrm{cm})\end{array}$} & \multicolumn{2}{|c|}{$\begin{array}{c}\text { Stem diameter } \\
(\mathrm{cm})\end{array}$} & \multicolumn{2}{|c|}{$\begin{array}{c}\text { No. of } \\
\text { branches/plant }\end{array}$} \\
\hline & Cut1 & Cut2 & Total & Cut1 & Cut1 & Total & Cut1 & Cut2 & Cut1 & Cut2 & Cut1 & Cut2 \\
\hline 1 & 32.3 & 29.3 & 61.5 & 3.710 & 3.394 & 7.104 & 73 & 80 & 0.800 & 0.700 & 7.0 & 9.0 \\
\hline 2 & 31.7 & 26.7 & 58.5 & 3.619 & 3.056 & 6.674 & 71 & 78 & 0.760 & 0.650 & 7.0 & 8.0 \\
\hline 3 & 33.2 & 30.5 & 63.7 & 3.881 & 3.722 & 7.602 & 75 & 82 & 0.850 & 0.740 & 7.0 & 9.0 \\
\hline 4 & 35.5 & 29.2 & 64.7 & 4.441 & 3.628 & 8.064 & 77 & 83 & 0.880 & 0.800 & 8.0 & 10.0 \\
\hline 5 & 33.5 & 29.0 & 62.5 & 3.767 & 3.336 & 7.103 & 72 & 78 & 0.780 & 0.660 & 7.0 & 8.0 \\
\hline 6 & 27.7 & 21.1 & 48.9 & 3.080 & 2.365 & 5.445 & 67 & 73 & 0.720 & 0.630 & 6.0 & 8.0 \\
\hline F.test & $* *$ & $* *$ & $* *$ & $* *$ & $* *$ & $* *$ & $* *$ & $* *$ & $* *$ & $* *$ & $* *$ & $* *$ \\
\hline L.S.D 0.01 & 2.196 & 2.676 & 3.524 & 0.243 & 0.379 & 0.510 & 3.027 & 3.213 & 0.093 & 0.066 & 0.751 & 0.688 \\
\hline L.S.D 0.05 & 1.589 & 1.935 & 2.549 & 0.336 & 0.274 & 0.364 & 2.190 & 2.324 & 0.067 & 0.048 & 0.543 & 0.498 \\
\hline
\end{tabular}

Table 7. Mean performance of the six cowpea genotypes for the four traits in 2015 season

\begin{tabular}{|c|c|c|c|c|c|c|c|c|c|c|c|c|}
\hline \multirow[t]{2}{*}{ Genotypes } & \multicolumn{3}{|c|}{ Fresh yield (kg/plot) } & \multicolumn{3}{|c|}{ Dry yield (kg/plot ) } & \multicolumn{2}{|c|}{$\begin{array}{c}\text { Plant height } \\
(\mathrm{cm})\end{array}$} & \multicolumn{2}{|c|}{$\begin{array}{c}\text { Stem diameter } \\
(\mathrm{cm})\end{array}$} & \multicolumn{2}{|c|}{$\begin{array}{c}\text { No. of branches/ } \\
\text { plant }\end{array}$} \\
\hline & Cut1 & Cut2 & Total & Cut1 & Cut1 & Total & Cut1 & Cut2 & Cut1 & Cut2 & Cut1 & Cut2 \\
\hline 1 & 30.0 & 29.0 & 59.0 & 3.652 & 3.304 & 6.897 & 74 & 80 & 0.830 & 0.780 & 8.0 & 9.0 \\
\hline 2 & 31.0 & 29.7 & 60.7 & 3.543 & 3.332 & 6.805 & 72 & 77 & 0.850 & 0.740 & 7.0 & 8.0 \\
\hline 3 & 32.0 & 30.7 & 62.7 & 3.841 & 3.505 & 7.345 & 75 & 83 & 0.860 & 0.820 & 8.0 & 9.0 \\
\hline 4 & 33.3 & 32.0 & 65.3 & 4.089 & 3.679 & 7.768 & 76 & 85 & 0.900 & 0.840 & 8.0 & 10.0 \\
\hline 5 & 32.0 & 30.3 & 62.3 & 3.776 & 3.395 & 7.170 & 74 & 78 & 0.800 & 0.780 & 8.0 & 9.0 \\
\hline 6 & 25.0 & 23.0 & 48.5 & 2.755 & 2.554 & 5.309 & 69 & 71 & 0.800 & 0.700 & 7.0 & 8.0 \\
\hline F.test & $* *$ & $* *$ & $* *$ & $* *$ & $* *$ & $* *$ & $* *$ & $* *$ & $* *$ & $* *$ & $* *$ & $* *$ \\
\hline L.S.D 0.01 & 1.942 & 1.271 & 2.415 & 0.191 & 0.228 & 0.349 & 3.120 & 4.842 & 0.066 & 0.066 & 0.543 & 0.766 \\
\hline L.S.D 0.05 & 1.405 & 0.919 & 1.747 & 0.264 & 0.105 & 0.252 & 2.257 & 3.502 & 0.048 & 0.048 & 0.393 & 0.554 \\
\hline
\end{tabular}

Genetic advance is more reliable index for selection of traits. It is rebuttable to highly additive gene effect (Ubi et al.2001). Ashkok et al. (2000) reached similar results and suggested mass selection breeding method as a mean of improvement of traits controlled by additive gene action.

\section{3-Variability after one cycle of Selection:}

Table (7) showed that the phenotypic variation and the value of PCV is higher than the values of the GCV for all traits except for plant height and the values of heritability which were highly significant for all traits under the study except for dry yield in $2^{\text {nd }}$ cut which had low percent with value of $48.5 \%$.

Also the genetic advance had high values for all the traits except dry yield $2^{\text {nd }}$ cut with value 38.6. Also low value observed for the stem diameter in $1^{\text {st }}$ cut and $2^{\text {nd }}$ cut with values of 15.4 and 16.6 , respectively. 


\section{Cluster analysis :-}

Results of cluster analysis are graphically illustrated in a dendrogram (Fig 1). Data revealed that the studied traits showed diversity among cowpea genotypes. At the first year, the data showed the lowest similarity level (43.98\%) between G1 and G3.On the other hand, the highest level of similarity was $96.62 \%$ between G20 and G21. The following level of similarity was $92.57 \%$ for (G22) which recorded between two nods (G11 and G13).
The dendrogram showed the relationships among the 24-cowpea genotypes according to the forage yield and its components (Fig 1). The genotypes were divided into two main groups and to sub group. The genotypes (3, 5, 10 and 9) were in one group, while genotypes (1, $7,2,4,6$ and 8$)$ were in different group and $(11,13,17$, $15,14,18,22,19,16,20,21,23,24$ and 12) in another group.

\section{Similarity}

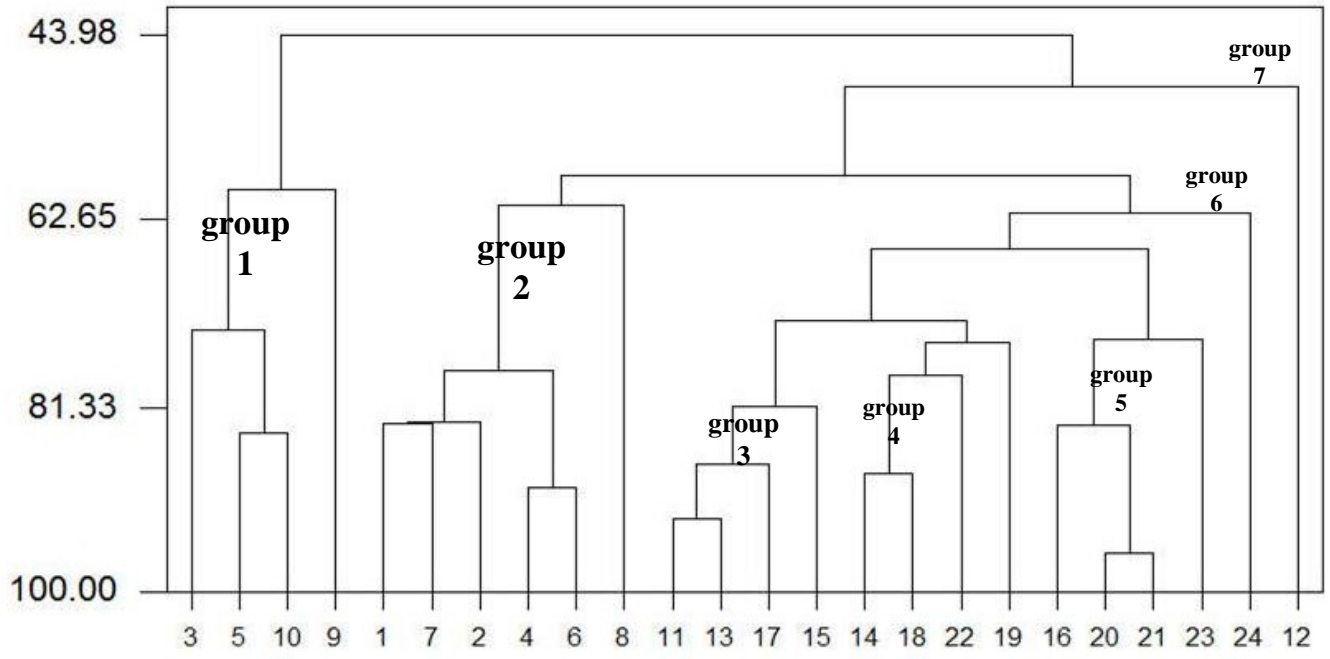

Fig. 1. Similarity levels of 24-cowpea genotypes calculated by cluster analysis using Euclidean Distance, Average Linkage based on agro- morphological traits

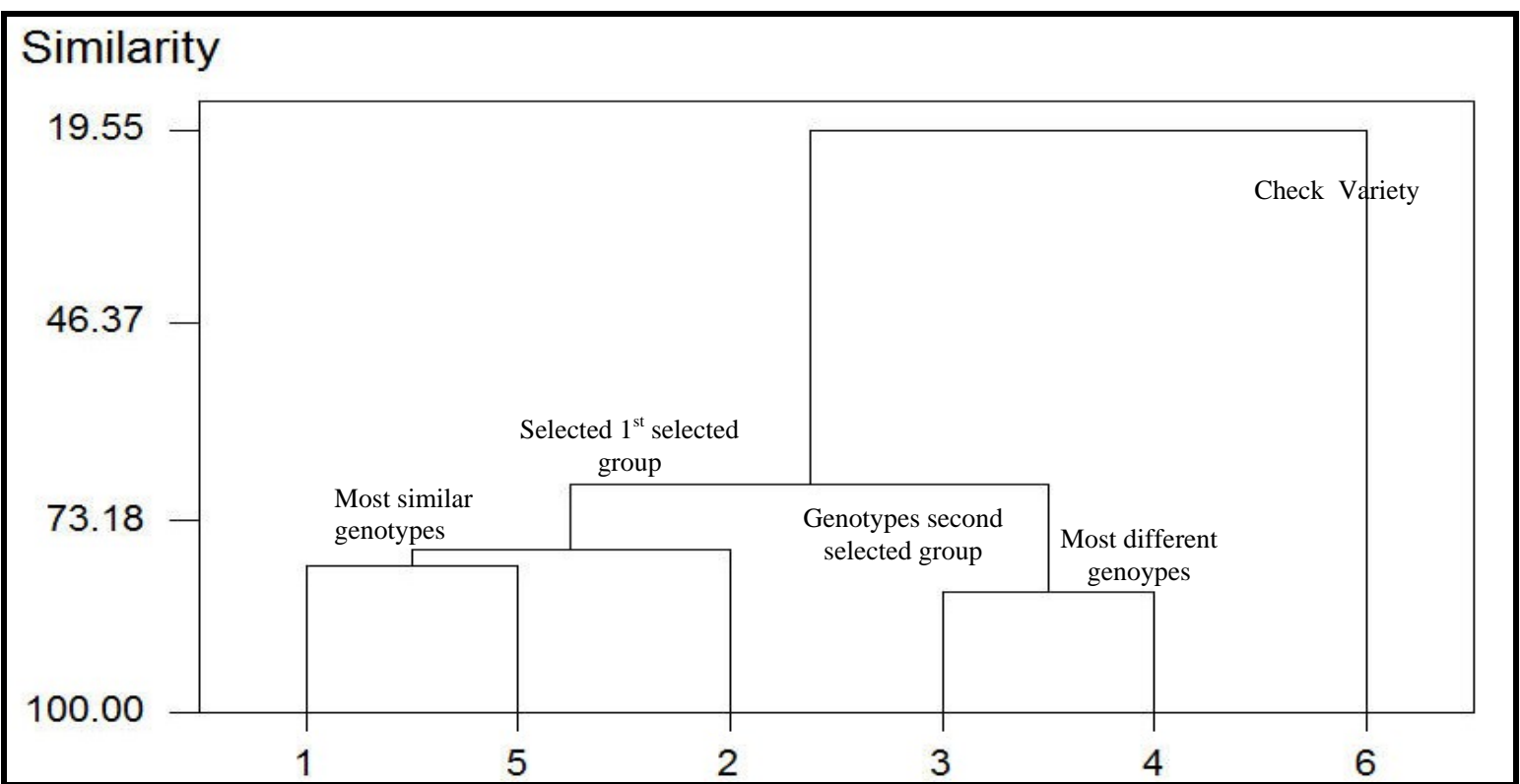

Fig. 2. Similarity levels for six-cowpea genotypes calculated by cluster analysis using Euclidean Distance, Average Linkage based on agro- morphological traits 


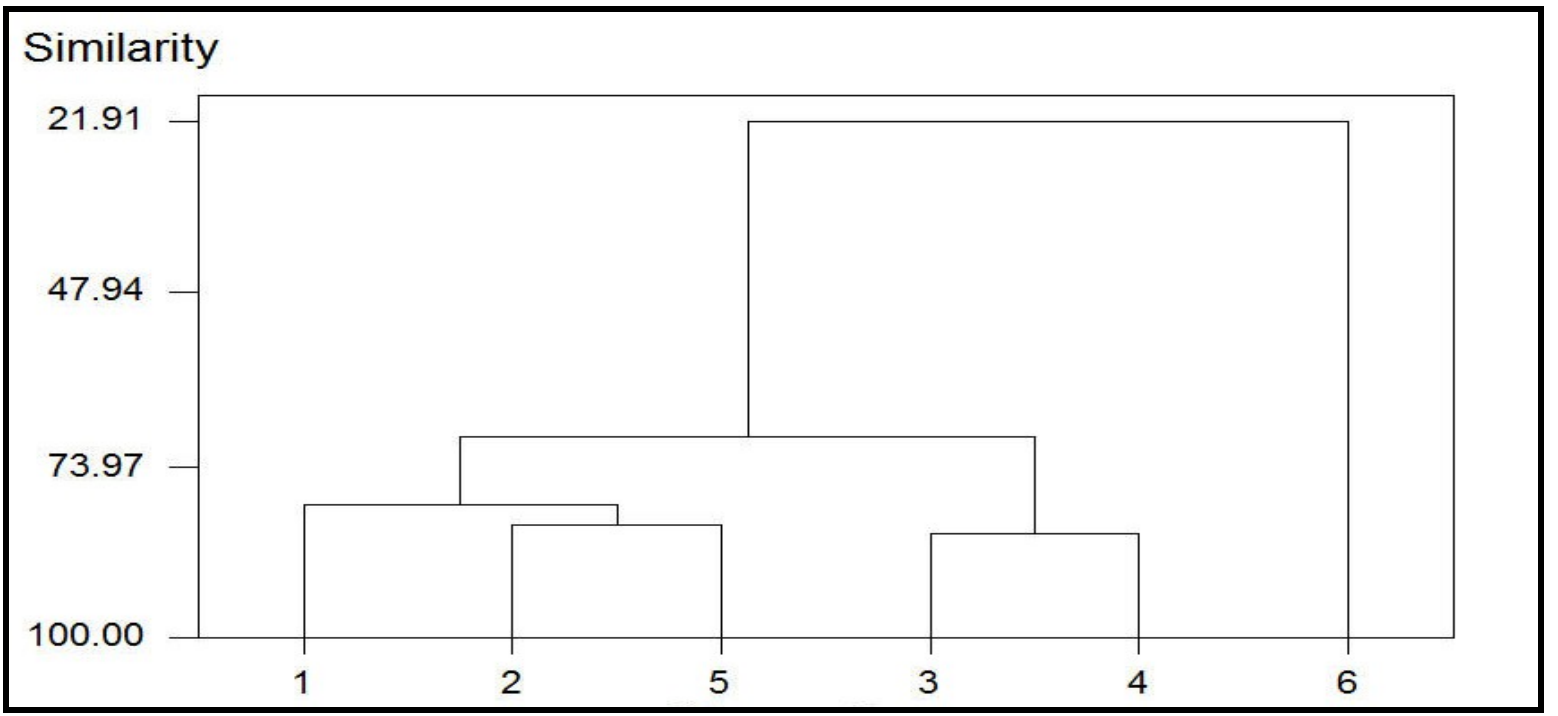

Fig. 3. Similarity levels of six cowpea genotypes calculated by cluster analysis using Euclidean Distance, Average Linkage based on agro- morphological traits in 2015

G20 and G21 were more closely related to each other where the similarity levels among them were more than 96.02. On the other hand, less similarity founded between G3 and G12. Therefore, there is diversity between the genotypes. Cluster analysis is considered a valuable tool for subdividing number of genotypes in groups including similarity and dissimilarity genotypes which it genotype might be classified in seven distinguished groups. Those are; group one includes genotypes $3,5,10,9$, group two includes genotypes 1 , $7,2,4,6,8, \ldots .$. , group three includes genotypes 11 , $13,17,15$, group four includes genotypes 14, 18, 22, 19 , group five includes genotypes $16,20,21,23$, group six includes genotypes 24 and group seven includes genotypes 12, may help in breeding program. These results are in agreement with Gad El-Hak, et al., (1988), Sultan et, al.(2016) and Khatab et al .,(2016).

(Fig. 2) and (Fig. 3) show the six genotypes at the second and third season. The results indicated that similarity level were 19.55 between two nodes G1 and G6 while, the highest similarity level were between G3 and G4 with similarity level 83.39 at the second season. Similar results were detected in the third year between the same genotypes with similarity level (21.91) for the lowest similarity value and (84.17) for the highest similarity value.

The dendrogram result showed that G6 was one main group and the G3 and G4 in subgroup and G1, G2 and $\mathrm{g} 5$ in second subgroup in both seasons. G3 and G4 are closely related to each other while G1 and G6 had dissimilarity with each other.

\section{CONCLUSIONS}

Evaluation and characterization as well as identification the suitable parents of cowpea germplasm are very crucial for improving the desired characters. The study showed that there is sufficient genetic variation among the 24 genotypes that can be employed for cowpea improvement program for the phenotypic characters. Genotype G4 could be used in intercrossing as parent to improve the dry yield as well as fresh yield. Regarding the similarity and dissimilarity genotypes G1 and G6 could be used for exploiting the hybrid vigor. Since the PCV seems from the results greater than the GCV we recommend evaluation the lines across different environments in Egypt.

\section{REFERENCES}

Alavindham, S. and L.D.V. Das. 1995. Crude fiber and crude protein contents in fodder cowpea - Ann. Agric. Res., 16:243-245.

Ashkok S., Lakshminarayanas and D. kumaresan. 2000. Variability studies in sunflower for yield and yield attributes. Journal of Oil Seeds Res. 17 (2): 239-241.

Damarany A.M. 1994. Estimates of genotypic and phenotypic correlation, heritability and potency of gene, set in cowpea (Vignaun guiculata L.) Assuit journal of Agric Sci. 25:1-8

Davis, D.W. D.B Marsh and M.N. Alvarez. 1986.M N13 and M N150 cowpea breeding lines. Hort. Sci. 2 (4): 1080-1081.

Denton, O.A. and C. Negbyruka. 2011. Heritability Genetic Advance and Character Association in six Releated Character of Solarium Enguivi - Asien Journal of Agriculture research Five:201-207. 
Dumet D., R. Adeleke, and B. Faloye. 2008. Regeneration guidelines of Cowpea in Dulloo ME, thornann 1, Jorge MA, Hanson J (eds.) Crop Specific Regeneration Gnidelines (cd - Rom)

FAO .2000. The State of Food in Seurity the World (SOFI). Rom, Italy. FAO, Un - 'LWW.FAOord/fous/e/sofiọ.e.htm.

Gad El-Hak S., H. Mohamoud and R.A. Ragob .1988. An evaluation study of twenty four genotypes of cowpea (Vignaua nguiculata (L.) walp) Minia J. Agric. Res and Dev. 10 (1): 257-268.

Hanson. G.H., H. F. Robinson, and R.E. Comsock.1956. Biometrical studies of yield in segregation populations of Korean lependeza. Agronomy Journal, 48: 287-282.

Hathout M. 1987. Production and management of dairy cattle in Egypt. Egyptian - Holland Workshop, Animal Production Res. Inst., March, 30-31.1987. Cairo. Egypt.

Iqbal, Z., M. Arashed, M. Ashres, T. Mahmoed. and A. Waheed. 2008. Evolution of Soybean (Glytine) Max (L.Merre.) Gerplasm for some important Morphical triats using Moix varieties analysis. Pak.or.P.O.T, 10(6). 2323-2328.

Johnson H.W., H.F. Robinson and R.E. Comstock.1955. Estimate of genetic and environmental variability in soybean. Agron. J. 47 (7): 314-318.

Khatab I. A., Akram R. Moesy, W.M. Fares and T, Kumarn. 2016. Genetic diversity of soybean genotypes evaluated by Agro- morphological and SSR markers.

Kohli, K.S. 2002. Variability for fodder yield and its components in cowpea. Range Management and Agro-forestry, 23: 149 - 151.

Kovach, W.T. 1995. Multivariate Statistics Package for IBMPc and Compatibles, Kovrach, Computing Service, 85 Nart. -Y- Delin, Pentreaeth, Anglesely LL 758 UY Wales, U.K.

Kravova - wade T., O. Diouf, T. Ndaye, C.E. Sall, S.B Raconnier and M. Neyra 2006. Water-condition effects on rhizobia competition for cowpea nodule occupancy. Afri. J. Biotech. 5: 1457-1463.

Kumar, R. and R.S. Sangwan. 2000. Genetic variability and heritability in cowpea (Vignaua nguiculata (L.) Walp) Ann. Biol., 16: 181-183.

Manggoel W, M.I.Uguru, O.N. Ndam. And M.A. Dosbak. 2012 Genetic variability, correlation and path coefficient analysis of some yield components of ten cowpea (Vignaua nguiculata (L.) walp) accessions. Journal of Plant Breeding and Crop Sci. 4: 80-86.

Musvosci, C. 2009. Morphical Charratcies and Enter relationship among def. Criptors In sun cowpea Genotype. Journal of African Science 9 501-507.

Nwosu D.J., B.D. Olatunbosun, and I. S. Adetiloye. 2013. Genetic variability heritability and genetic advance in cowpea genotypes in two agroecological environments. Greener Journal of Biological scis.3:202-207.

Ogbonnaya C.I, B. Sarr, C.B Rou, O. Diouf, N.N. Diop and H. Roymacanly 2003. Selection of cowpea in hydroponics, pots and field for drought tolerance. Crop Sci. 43: 1114-1120.

Omogui L.O. I., M.F.Shiyaku, A.Y. Kamara, S.O. Alabi, and S.G. Mohammed . 2006. Genetic variability and heritability studies of some reproductive in cowpea (Vigna unguiculta (L.) walp.) African Journal of Biotechnology. 5(13): 1191-1195.

Pathmanathan, U., R.P. Ariyanayagam, and S.O. Haque. 1977. Genetic analysis of yield and its component in vegetable cowpea (Vigna unguiculata L. Walp.) Euphytica, 96 (2): 207-2013.

Rashwan A. 2010. Estimates of some genetic parameters using six population of two cowpea hybrids. Asian Journal of Crop Sci. 2: 261-266.

Rboinson H., and Comstock, R.F. 1955. Estimates of Genetic and Environmental variability soybean. Agronomy Journal for three: $314-318$.

Rome. CGIAR system - Wide Genetic Resource Programme. Musvosvic. 2009. Morphological characterization and interrelationships among descriptors in some cowpea genotypes. J. of African Crop sci. 9: $501-507$.

Sharawy Wafaa. M. and Z. Ael-fiky .2003. Characterization of cowpea (Vigna. Unguiculata(L.) walp) genotypces based on yield traits and RAPDPCR analysis Arab J. Biotech. 6 (1): 67-78.

Sultan Fadia M., Azza Khalil and S. Salem. 2016. Evaluation of some cowpea genotypes in Egypt for growth yield and quality traits. Egyptian Journal of Plant Breed. 20(4): 593-608.

Ubi E.B, H. Mignouna, and G. Obigbeson. 2001. Segregation for seed weight, pod length and days to flowering following cowpea cross. African Crop Science Journal, 9(3):463-470

Uguru M.I. 1995. Heritable relationships and variability of yield components in vegetable cowpea. African Crop Sci. Journal 3(1) :23-28. 


\title{
الملخص العربي
}

\section{الصفات الزراعية المورفولوجية والثوابت الوراثية لبعض التراكيب الوراثية في لوبيا العلف العفير}

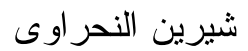

حيث أظهرت النتائج في موسم با ـrم ان درجة التوريث تراو احت مابين 9, • ٪\% الى 99\% لصفة سمك الساق في الحشة الأولي ومحصول العلف الأخضر في الحشة الثانية

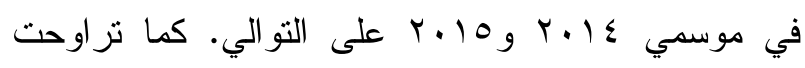

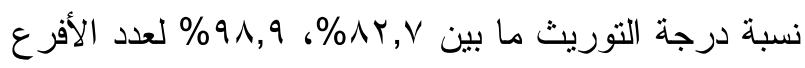

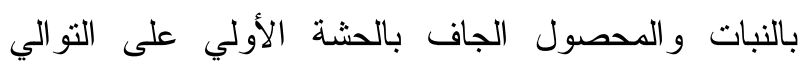

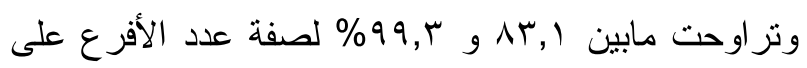
النبات بالحشة الأولية والمحصول الأخضر بالحشة الثانية

$$
\text { على التو الي في موسم } 10 \text { • ب م. }
$$

كما أظهرت نتائج تحليل المجاميع او تجربة النسب

إستتادا الى الصفات المورفولوجية فروق معنوية بين التز اكيب خلال كل الصفات المدروسة ونسبة تشابة عالية

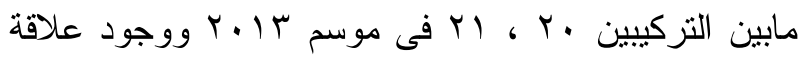

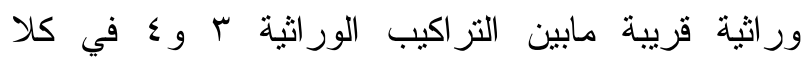

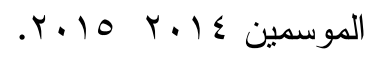

يعتبر تحليل التباين بين التراكيب الوراثية المختلفة

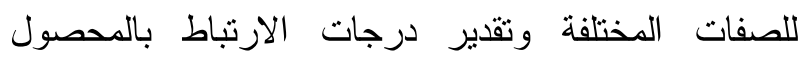
ودرجة التوريث ودرجة القرابة من الأهمية بما كان لنجاح برامج التربية المختلفة. تمت إقامة التجارب الخاصة بهذه الدر اسة في محطة بحوث سخا الزر اعية - مركز البحوث

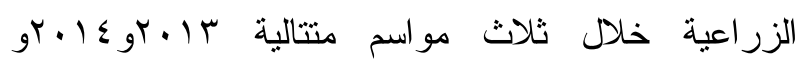

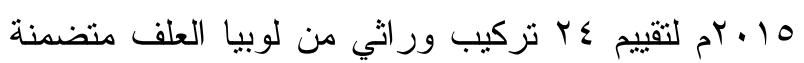
الصنف التجاري (لوبيا بلدي) و انتخاب أفضلها. حيث أظهرت النتائج أن التركيب الوراثى (ع ) تفوق علي باقي

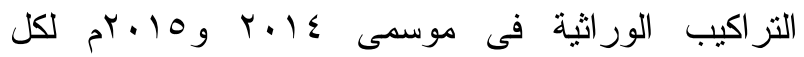
الصفات المدروسة. واظهرت النتائج وجود فروق معنوية

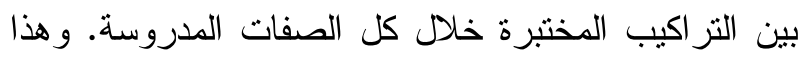
يوضح امكانية الانتخاب و استخدام بر امج التربية اعتمادا على هذه الصفات مستخدماً تلك التز اكيب الور اثية كما كانت هناك فروق كبيرة بين التزاكيب الوراثية لمعظم الصفات

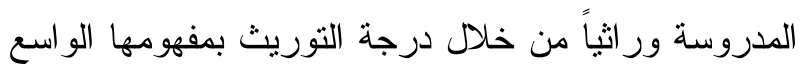

